\title{
Integrated pest management in potato with special reference to ITK
}

K. H. Begum ${ }^{1}$, R. K. Nath* and P. Ahmed

Krishi Vigyan Kendra (A.A.U.), Tinsukia (Assam) India

${ }^{1}$ District Agriculture Office, Tinsukia (Assam) India

\section{ARITCLE INFO}

Received : 21.04 .2018

Revised : 03.09 .2018

Accepted : 18.09 .2018

\section{KEY WORDS :}

IPM, Mole cricket, Red ant, Malathion, Ridomil MZ-72

*Corresponding author: rupaknath09@gmail.com

\begin{abstract}
An experiment was conducted in the Horticultural orchard of Assam Agricultural University, Jorhat from 2014-15 and 2015-16 to develop IPM module against pest and diseases of potato. Ten different IPM modules were followed against the target pest and diseases. Out of these, the IPM module consisting of soil application of MOC followed by high ridge planting and use of yellow sticky trap followed by application of malathion 5 per cent dust and Ridomil MZ-72 @ 0.01\% recorded lowest infestation of mole cricket and red ant with 3.42 and 7.71 per cent, respectively with a highest yield of $248.61 \mathrm{q} / \mathrm{ha}$. Likewise, the per cent increase in yield and benefit cost ratio was observed highest (8.54) in the module with low incidence of late blight and leaf roll disease.
\end{abstract}

How to view point the article : Begum, K.H., Nath, R.K. and Ahmed, P. (2018). Integrated pest management in potato with special reference to ITK. Internat. J. Plant Protec., 11(2) : 141145, DOI : 10.15740/HAS/IJPP/11.2/141-145, Copyright@ 2018: Hind Agri-Horticultural Society. 